\title{
The linkages among hillslope-vegetation changes, elevation, and the timing of late-Quaternary fluvial-system aggradation in the Mojave Desert revisited
}

\author{
J. D. Pelletier \\ Department of Geosciences, University of Arizona, Gould-Simpson Building, 1040 East Fourth Street, Tucson, \\ Arizona 85721-0077, USA
}

Correspondence to: J. D. Pelletier (jdpellet@email.arizona.edu)

Received: 8 March 2014 - Published in Earth Surf. Dynam. Discuss.: 24 March 2014

Revised: 4 July 2014 - Accepted: 14 July 2014 - Published: 21 August 2014

\begin{abstract}
Valley-floor-channel and alluvial-fan deposits and terraces in the southwestern US record multiple episodes of late-Quaternary fluvial-system aggradation and incision. Perhaps the most well-constrained of these episodes took place from the latest Pleistocene to the present in the Mojave Desert. One hypothesis for this episode - i.e., the paleovegetation-change hypothesis $(\mathrm{PVCH})$ - posits that a reduction in hillslope vegetation cover associated with the transition from Pleistocene woodlands to Holocene desert scrub generated a pulse of sediment that triggered a primary phase of aggradation downstream, followed by channel incision, terrace abandonment, and initiation of a secondary phase of aggradation further downstream. A second hypothesis i.e., the extreme-storm hypothesis - attributes episodes of aggradation and incision to changes in the frequency and/or intensity of extreme storms. In the past decade a growing number of studies has advocated the extremestorm hypothesis and challenged the PVCH on the basis of inconsistencies in both timing and process. Here I show that in eight out of nine sites where the timing of fluvial-system aggradation in the Mojave Desert is reasonably well constrained, measured ages of primary aggradation are consistent with the predictions of the $\mathrm{PVCH}$ if the time-transgressive nature of paleovegetation changes with elevation is fully taken into account. I also present an alternative process model for $\mathrm{PVCH}$ that is more consistent with available data and produces sediment pulses primarily via an increase in drainage density (i.e., a transformation of hillslopes into low-order channels) rather than solely via an increase in sediment yield from hillslopes. This paper further documents the likely important role of changes in upland vegetation cover and drainage density in driving fluvial-system response during semiarid-to-arid climatic changes.
\end{abstract}

\section{Introduction and motivation}

Quaternary deposits of the southwestern US are dominated by valley-floor-channel and alluvial-fan deposits and their associated terraces that record multiple regionally correlative episodes of aggradation, channel incision, and terrace abandonment (Christensen and Purcell, 1985; Bull, 1991; Harvey et al., 1999; Menges et al., 2001; McDonald et al., 2003; Anders et al., 2005). What drives these aggradation and incision episodes has been a fundamental question in the geomorphology and Quaternary geology of the southwestern US for decades. Given the approximate correlation between the timing of fluvial-system aggradation events and semiarid-toarid transitions recorded in paleoclimatic proxies, together with the correlative nature of Quaternary deposits and terraces across tectonically active and inactive regions, climate change has most often been invoked as the primary trigger for these episodes. How climate change drives episodes of aggradation and incision is debated, however.

In this paper I focus on the timing and mechanisms of fluvial-system aggradation and incision in the Mojave Desert portion of the southwestern US from the latest Pleistocene to the present. I focus on this study area and this time interval because the constraints on both fluvial-system behavior 
and its potential driving mechanisms are arguably better constrained than for any other area and any other time interval in the world that has experienced a semiarid-to-arid climatic change. For example, the timing of local paleovegetation changes is unusually well constrained; i.e., 87 dated packrat middens within the central Mojave Desert exist with woodland species (Juniperus) clearly present or absent from 17 to $0 \mathrm{ka}$. Also, dozens of state-of-the-art stratigraphic and surface-exposure ages have been obtained (e.g., Miller et al., 2010; Antinao and McDonald, 2013a, and references therein). Semiarid-to-arid climatic transitions are of particular interest given that semiarid landscapes may be particularly sensitive to climatic changes (e.g., Langbein and Schumm, 1958) and because large portions of earth's surface have the potential to transition from semiarid to arid climates in the future (e.g., Held and Soden, 2006; Lau et al., 2013). More broadly, drainage basin responses to climatic changes are mediated in large part through changes in vegetation cover, and understanding the feedbacks between vegetation cover and landscape evolution has emerged as a "grand challenge" problem in earth surface science (e.g., Murray et al., 2009; Reinhardt et al., 2010). As such, understanding the late-Quaternary record of fluvial-system response to climatic changes in the Mojave Desert has the potential to enhance our conceptual understanding of how vegetation cover and landforms coevolve in other process zones.

In his work on the paleovegetation-change hypothesis $(\mathrm{PVCH})$ for fluvial-system response to climatic changes in the southwestern US, Bull (1991) argued that a reduction in vegetation cover during late-Quaternary semiarid-to-arid transitions led to sediment pulses characterized by an initial increase in sediment yield (resulting in aggradation in valley-floor channels and/or alluvial fans downstream) followed by a decrease in sediment yield as the reservoir of colluvium stored on hillslopes was depleted (resulting in channel incision and terrace abandonment). As Bull (1991) wrote, "when the climate changes from semiarid to arid, the concurrent decrease in vegetation cover results in a rapid increase in sediment yield. The sediment-yield maximum is attained quickly, after which the yield progressively decreases as the area of hillslope colluvium decreases and outcrop area increases." (p. 113). Bull (1991) also invoked changes in the frequency and/or intensity of extreme storms; i.e., "hillslope sediment yields were greatly increased - partly because of increased rainfall intensities associated with the return of monsoon thunderstorms" (p. 114). As such, Bull (1991) did not envision the PVCH working in isolation. Which of these two driving mechanisms (paleovegetation changes or an increase in the frequency and/or intensity of extreme storms) plays a greater role in driving fluvial-system aggradation and incision has been a subject of controversy ever since Bull's seminal work.

As the dating of fluvial-system deposits in the Mojave Desert has improved over the past 2 decades, numerous studies have used the apparently poor correlation between the

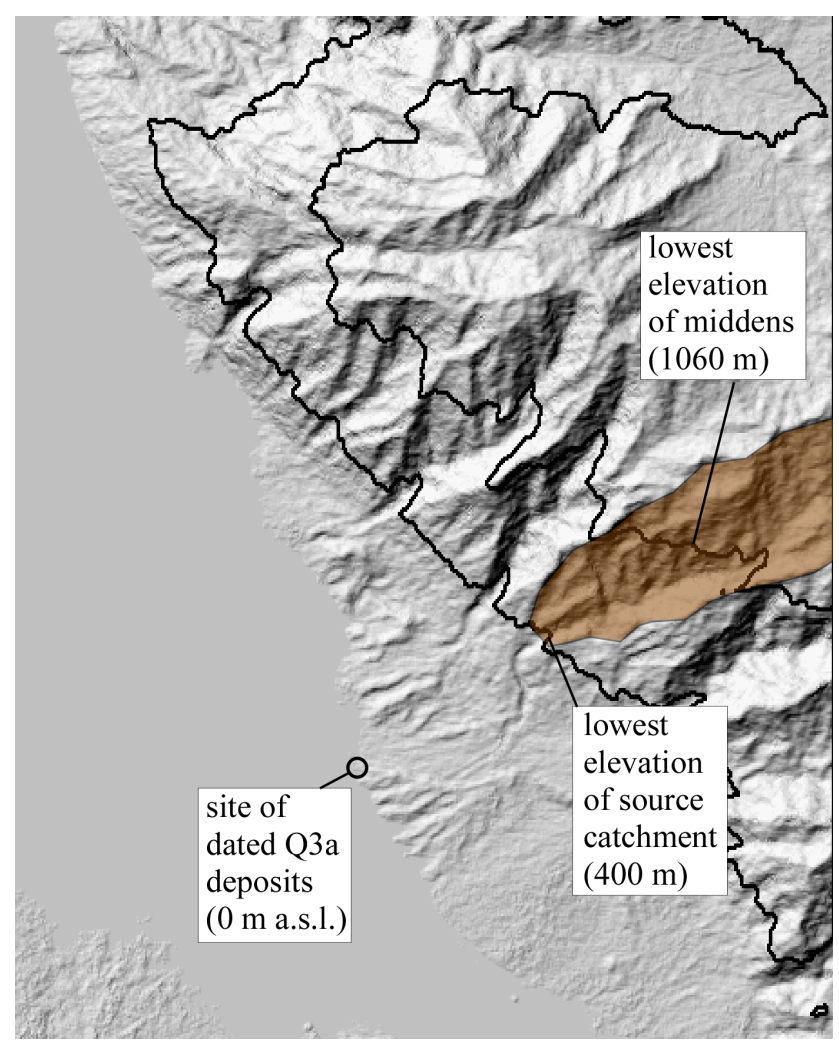

Figure 1. Illustration of the key elevations associated with the southern Death Valley fan-aggradation site, using a shaded-relief image as a base map. Location is shown in Fig. 4. Samples were collected by Sohn et al. (2007) at approximately $0 \mathrm{~m}$ a.s.l. The timing of the initiation of fan aggradation is controlled, according to the PVCH, by the timing of the retreat of the lower elevational limit of woodland vegetation through the lowest elevations of the source catchment; i.e., $400 \mathrm{~m}$ a.s.l. In their central Mojave subregion, Antinao and McDonald (2013a) used midden records with lowest elevations of $1060 \mathrm{~m}$ a.s.l. (Supplement of Antinao and McDonald, 2013a), resulting in an elevational gap of approximately $600 \mathrm{~m}$. This gap produces a $6 \mathrm{ka}$ cal (calibrated)time lag between assumed and actual paleovegetation changes in the lowest elevations of the source catchment.

timing of paleovegetation changes and alluvial-fan aggradation to argue against the PVCH. For example, in the central Mojave subregion of their study, Antinao and McDonald (2013a) tested the PVCH by comparing the timing of fan aggradation at a site (southern Death Valley - DV) sourced by an eroding catchment with lowest elevations of $\approx 400 \mathrm{~m}$ a.s.l. (above sea level) against the timing of paleovegetation changes constrained by a group of nearby packrat midden sites (which record the vegetation types within a $100 \mathrm{~m}$ range) with a lowest elevation of $1060 \mathrm{~m}$ a.s.l. (Granite Mountains) (Fig. 1; Supplement of Antinao and McDonald, 2013a). This approximately $600 \mathrm{~m}$ gap in elevation between the lowest elevations of the source catchment and the lowest elevation where the timing of paleovegetation changes 
was constrained is problematic because, as I demonstrate in Sect. 2, the transition from woodlands to desert scrub measured at $1060 \mathrm{~m}$ a.s.l. occurred $6 \mathrm{ka}$ after vegetation changes in the lowest elevations of the source catchment (i.e., the portion of the catchment responsible for triggering the initiation of fan aggradation according to the $\mathrm{PVCH}$ ). Antinao and McDonald (2013a) concluded that the onset of fluvial-system aggradation "began well before changes in catchment vegetation cover" and, as a result, that "the ambiguous relation between vegetation change and alluvial fan aggradation indicates that vegetation had a reduced role in LPH aggradation". To test the PVCH most comprehensively, however, it is necessary to constrain the timing of the woodland-to-desertscrub transition at the lowest elevations of each source catchment because vegetation changes are time-transgressive with elevation (occurring first at low elevations and later at high elevations) and hence it is the vegetation changes at the lowest elevations of source catchments that are responsible for triggering aggradation according to the PVCH (McDonald et al., 2003; Sect. 2 in this paper).

Miller et al. (2010) concluded that alluvial-fan aggradation in the Mojave Desert was principally due to more frequent and/or more intense storms based on an approximate correlation between the timing of alluvial-fan aggradation and elevated sea-surface temperatures in the Gulf of California (a proxy for monsoon activity). Specifically, both records exhibit two peaks from the latest Pleistocene to the present; i.e., one at ca. 15-7 ka cal BP (calibrated years, before present) and another at ca. 6-3 ka cal BP. The dual-pulsed nature of alluvial-fan aggradation from the latest Pleistocene to present was also emphasized by Bull (1991), who noted "the aggradation event that was associated with the PleistoceneHolocene climate change consisted of two main pulses $(\mathrm{Q} 3 \mathrm{a}$ and Q3b) with an intervening period of stream-channel incision" (p. 114). Miller et al. (2010) considered the dualpulsed nature of aggradation to be inconsistent with $\mathrm{PVCH}$. However, two pulses of aggradation separated by approximately 4-8 ka and resulting from a single pulse of sediment yield is precisely what the $\mathrm{PVCH}$ predicts (documented in Sect. 2). A sediment pulse from upstream catchments can overwhelm the ability of a downstream valley-floor channel or alluvial fan to convey that increase in sediment, leading to a "primary" phase of aggradation. When sediment supply declines during the waning phase of the sediment pulse, fluvial channels incise into the sediments just deposited and an abandoned terrace is formed. Sediments reworked by channel incision, along with sediments still being supplied by the catchment in the waning phase of the sediment pulse, are then deposited in a "secondary" deposit further downstream (Fig. 2a). In this way, a single pulse of sediment can generate two deposits separated by channel incision, as Bull (1991) stated and as Schumm's (1973) concept of complex response formalized.

The PVCH has also been criticized on the basis of process. The conceptual process model that underpins the $\mathrm{PVCH}$ as
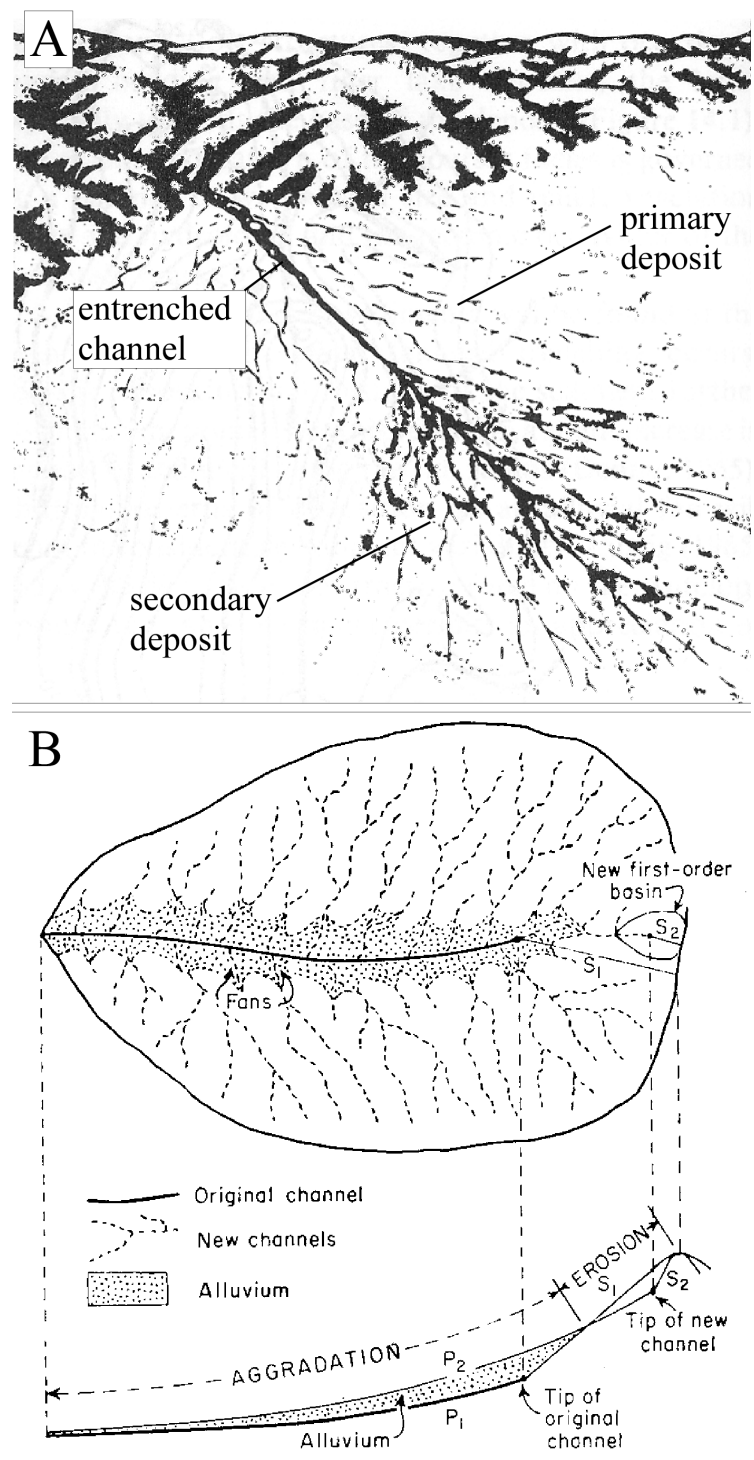

Figure 2. Schematic diagrams drawn from the literature illustrating (a) fan and (b) source-catchment responses to semiarid-to-arid transitions. (a) Illustration of paired deposits (i.e., a secondary deposit downstream and inset into a primary deposit) resulting from a single pulse of sediment (from Bull, 1968). In (a), a pulse of sediment from upstream catchments leads to a "primary" phase of aggradation. When sediment supply declines during the waning phase of the sediment pulse, fluvial channels incise into the sediments just deposited and an abandoned fan terrace is formed. Sediments reworked by channel incision, along with sediments still being supplied by the catchment in the waning phase of the sediment pulse, are then deposited in a "secondary" deposit farther downslope. (b) Schematic diagram illustrating the response of a catchment to an increase in erosivity (from Strahler, 1968). Low-order drainages grow headward, converting hillslopes, and into low-order fluvial channels capable of rapidly transporting material stored as colluvium during the previous period. When channels cease growing headward (i.e., when the catchment stabilizes to a new, higher drainage density), the pulse of sediment wanes and channel incision/secondary aggradation is triggered (not shown). 
proposed by Bull (1991) requires that hillslopes be stripped nearly to bedrock in some locations, increasing the area of outcrops in the catchment and hence reducing the availability of soil for transport, triggering channel incision and terrace abandonment downstream (Bull, 1991). McDonald et al. (2003) correctly argued that Bull's (1991) conceptual model is inconsistent with the observed abundance of soils on, and the high-infiltration capacity of, many Holocene desert hillslopes in the Mojave Desert. Modeling studies (discussed in Sect. 3), however, together with the correlation of drainage density with both aridity and percent bare area in catchments of the southwestern US (Melton, 1957), suggest that the principal effect of a reduction in vegetation cover is not an increase in sediment yield from hillslopes but rather an increase in drainage density as hillslopes are converted into low-order channels capable of rapidly entraining colluvium into the fluvial system (Fig. 2b; Strahler, 1958; Tucker and Slingerland, 1997; Pelletier et al., 2011). As such, some modification of the process model underlying the PVCH is necessary even if the PVCH can be shown to exhibit timing that is consistent with available data. More recently, Antinao and McDonald (2013a) challenged the PVCH by noting that Pierson et al. (2007) documented a minimal increase in erosion following the manual removal of Juniperus from hillslopes. The Pierson et al. (2007) study is not a proper analog for the woodland-to-desert-scrub transition from the latest Pleistocene to the present in the Mojave Desert; however, because that study was performed in Oregon, erosion was measured in plots less than $10 \mathrm{~m}$ wide, and juniper root systems and fallen trees were left intact at the site after cutting (i.e., vegetation cover near the ground surface was higher after cutting than before). In contrast, vegetation cover would be lower and percent bare area would be higher following a woodlandto-desert-scrub transition that occurred over timescales of millennia.

In this paper I first quantify the timing of the retreat of the woodland-to-desert-scrub transition to higher elevations from the latest Pleistocene to the present within the Mojave Desert using all available data from the North American Midden Database of Strickland et al. (2005). Second, I report on the results of a geographic-information-system (GIS)-based analysis that accepts, as input, the timing of woodland-todesert-scrub transition and a digital elevation model (DEM), and predicts the timing of both the initiation of primary aggradation and channel incision/secondary aggradation as predicted by the PVCH. Thirdly, I compare the predictions of the model to available geochronologic data from the Mojave Desert. My analysis demonstrates that the timing of fluvialsystem aggradation from the latest Pleistocene to the present in the Mojave Desert is consistent with the PVCH in eight out of nine sites in the Mojave Desert where the timing is reasonably well constrained. Fourthly, I demonstrate consistency in the relationship between modern vegetation cover and elevation as a function of latitude within the Mojave Desert in order to provide a basis for assuming that the timing of veg- etation changes as a function of elevation are relatively uniform throughout the study region. Finally, I present an improved process model of how the PVCH works, which includes transient changes in drainage density associated with semiarid-to-arid climate transitions.

\section{A test of the PVCH for the Mojave Desert}

In this section I reexamine the conclusions of Antinao and McDonald (2013a) using the same data but a different methodology. Rather than grouping fan-aggradation and paleovegetation sites according to spatial proximity and elevation ranges that are similar but nevertheless are associated with differences in the timing of assumed versus actual paleovegetation changes of up to $6 \mathrm{ka}$, my methodology honors the dominant role of elevation in controlling plant distributions in the Mojave Desert by first quantifying the relationship between the elevational lower limit of woodland plants versus time in the Mojave Desert and then applying that relationship to a GIS analysis that predicts the timing of both primary aggradation and channelincision/secondary-aggradation based on the timing of the woodland-to-desert-scrub transition in the source catchments upstream from every point on the landscape. In both Antinao and McDonald (2013a) and this study, the commonness/abundance of Juniperus is used as a proxy for woodland versus desert scrub (i.e., Juniperus rare/absent) vegetation types. Where biomass data are available in the southwestern US, the woodland-to-desert-scrub transition is associated with a step change in biomass (e.g., Whittaker and Niering, 1975). Since woody biomass "reduces runoff and overlandflow erosion by improving water infiltration, reducing impacts by water droplets, intercepting rain and snow, and physically stabilizing soil by their roots and leaf litter" (Kort et al., 1998), a transition from commonness/abundance to rarity/absence of Juniperus is likely to also be associated with a step-change increase in sediment supply to fluvial systems downstream.

I analyzed the North American Midden Database (Strickland et al., 2005) to identify the elevational lower limit of Juniperus as a function of time from the latest Pleistocene to the present in the Mojave Desert (Fig. 3). The solid curve in Fig. 3, which correctly differentiates all 87 (within $2 \sigma$ uncertainty; one rare/absent Juniperus data point lies to the left of the solid curve but the solid curve is consistent with that point within the $95 \%$ confidence interval) available localities in terms of common/abundant versus rare/absent Junipe$r u s$, illustrates the dominant role of elevation in controlling woodland versus desert scrub vegetation types from 17-0 ka cal BP. The consistency of the data - i.e., within age uncertainty all common/abundant records reside on one side of the solid curve in Fig. 3 and all rare/absent records reside on the other side - provides confidence in using the curve to predict the timing of the woodland-to-desert-scrub transition 


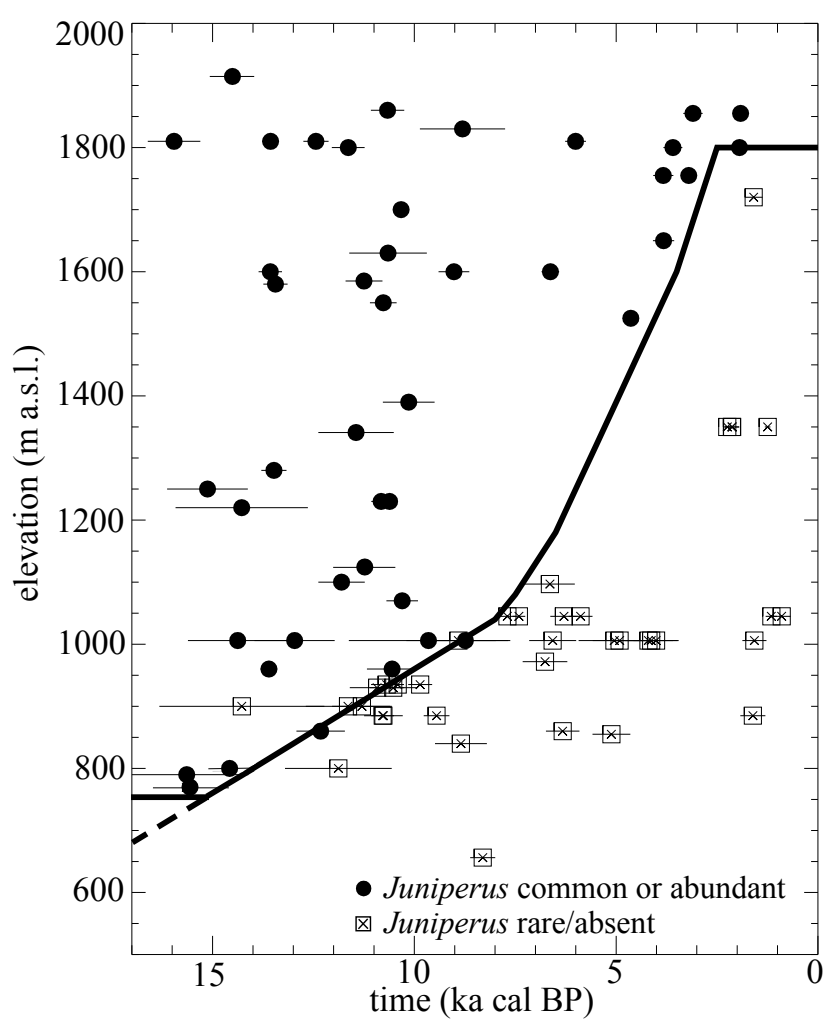

Figure 3. Plot of every midden in the North American Midden Database (Strickland et al., 2005) between 34 and $37^{\circ} \mathrm{N}$ latitude, 117.5 and $115^{\circ} \mathrm{W}$ longitude, and 500 and $2000 \mathrm{~m}$ a.s.l., and 1 and $17 \mathrm{ka}$ in age (cal BP; ${ }^{14} \mathrm{C}$ years were converted using IntCal09 of Reimer et al. (2009); $95 \%$ confidence intervals are shown) with $J u$ niperus common/abundant (closed circles; total of 46 samples) and Juniperus rare/absent (open squares; total of 41 samples). In the latter cases, Juniperus is specifically noted as absent or a complete taxa list is available that does not include Juniperus. The solid curve is the lower elevational limit of woodlands adopted in the model. The dashed line indicates that the lower limit of common/abundant $J u$ niperus is poorly constrained from 17 to $15 \mathrm{ka} \mathrm{cal} \mathrm{BP}$.

within source catchments upstream from aggradation sites in the Mojave Desert using elevation data. The elevation-age relationship (i.e., solid curve in Fig. 3) for the lower limit of Juniperus is well constrained in the $15-10 \mathrm{ka}$ cal BP interval but significantly less well constrained in the 10-3 ka cal BP interval. However, this uncertainty has little practical effect on the comparison of the model predictions to data because the predicted age of initiation of primary aggradation is between 15 and $10 \mathrm{ka}$ cal BP for all of the sites except two (Johnson Valley and Grassy Valley; Table 1).

Primary aggradation is assumed to be initiated downstream when a small but significant portion $(5 \%$ is used here) of the source catchment area (defined as upstream areas with slopes $>20 \%$ ) changes from commonness/abundance to rarity/absence of Juniperus (Figs. 4-6). Primary aggradation is assumed to terminate when $50 \%$ of the source catch-

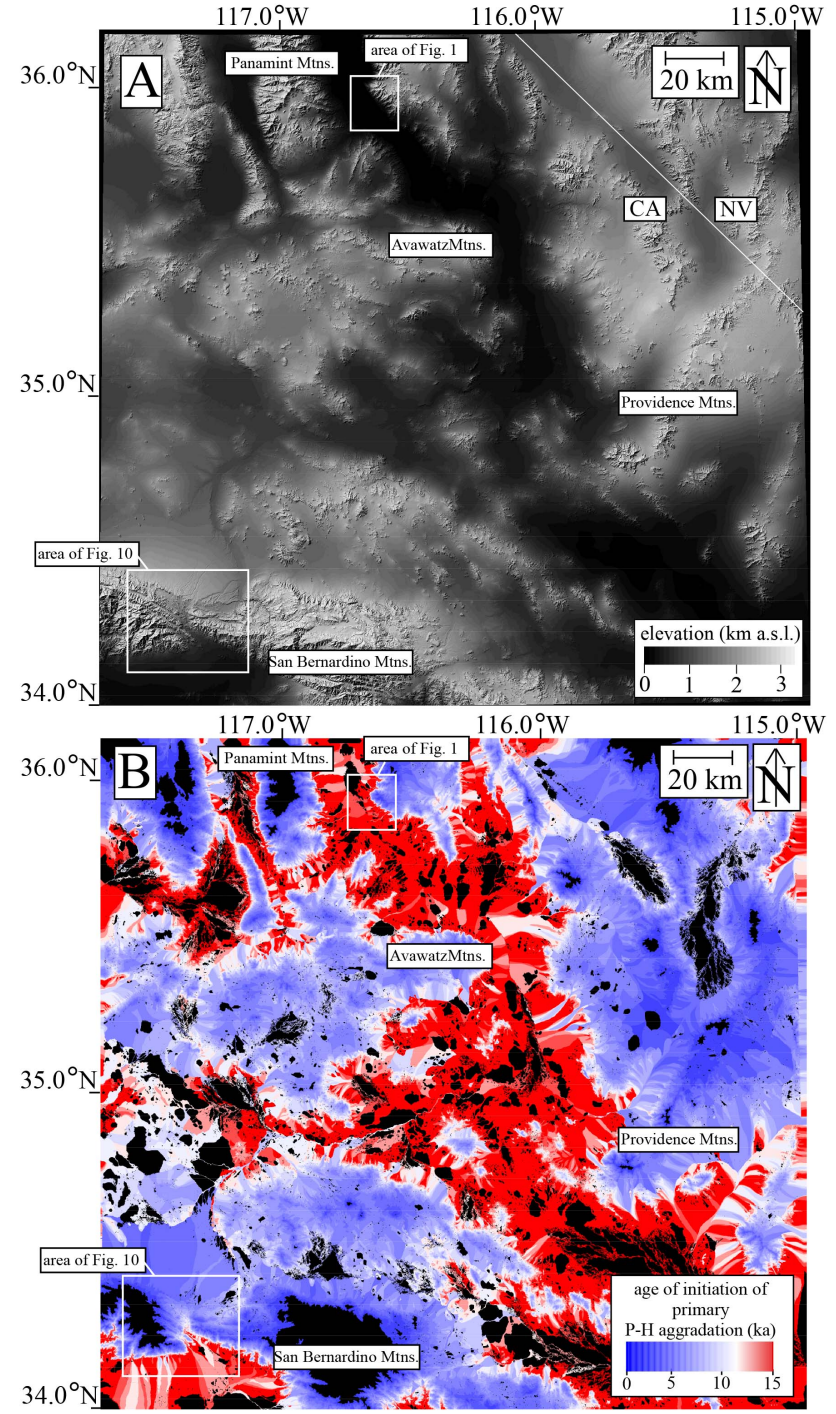

Figure 4. (a) Shaded-relief map of the study area. (b) Color map of the model-predicted age of initiation of primary aggradation (i.e., unit Q3a of Bull, 1991) where deposits of such ages are present. Reddish areas indicate Pleistocene-aged Q3a deposits while bluish areas indicate Holocene-aged (0-11.7 ka cal BP) Q3a deposits (if Q3a deposits are present). Black areas are locations not downstream (based on flow pathways defined by the modern DEM) from areas that have undergone $\mathrm{P}-\mathrm{H}$ (Pleistocene-Holocene) changes in $\mathrm{Ju}$ niperus cover.

ment area has transitioned from commonness/abundance to rarity/absence of Juniperus, at which point the source area for sediment derived from woodlands-to-desert-scrub transition is assumed to decline over time, triggering channel incision, terrace abandonment, and secondary aggradation further downstream.

The GIS analysis that predicts the timing of the onset of primary aggradation and the timing of channel incision/onset of secondary aggradation begins by associating each pixel 
Table 1. Comparison of available data and model predictions for the timing of fluvial-system aggradation and incision from the latest Pleistocene to the present. Sites are listed in order of increasing elevation to highlight the relationship between elevation and the age of initiation of primary aggradation in the data and model (UTM - Universal Transverse Mercator; V. - Valley).

\begin{tabular}{|c|c|c|c|c|c|c|c|}
\hline Locality & $\begin{array}{r}\text { UTM } \\
\text { Easting } \\
(\mathrm{m})^{5}\end{array}$ & $\begin{array}{r}\text { UTM } \\
\text { Northing } \\
(\mathrm{m})\end{array}$ & $\begin{array}{r}\text { Elevation } 6 \\
(\mathrm{~m} \text { a.s.1. })\end{array}$ & $\begin{array}{r}\text { Predicted } \\
\text { initiation primary } \\
\text { aggrad. }^{3}(\mathrm{ka} \mathrm{BP})\end{array}$ & $\begin{array}{l}\text { Predicted } \\
\text { incision }^{3} \\
(\mathrm{ka} \mathrm{BP})\end{array}$ & $\begin{array}{r}\text { Measured } \\
\text { initiation primary } \\
\text { aggrad. }^{2}(\mathrm{ka} \mathrm{BP})\end{array}$ & $\begin{array}{l}\text { Measured } \\
\text { incision }^{1} \\
(\mathrm{ka} \mathrm{BP})\end{array}$ \\
\hline Southern DV ${ }^{7}$ & $525510^{6}$ & $3978760^{6}$ & 0 & $15 \pm 2$ & $8 \pm 2$ & $17.4 \pm 2.4$ & $10.7 \pm 1.54$ \\
\hline Chambless $^{8}$ & 639525 & 3818044 & 250 & $15 \pm 2$ & $8 \pm 2$ & $<9.4 \pm 0.67^{4}$ & N/A \\
\hline Kelso Wash ${ }^{8}$ & 594631 & 3876604 & 360 & $13 \pm 2$ & $5 \pm 2$ & $<13.3 \pm 0.7$ & N/A \\
\hline Red Pass ${ }^{9}$ & 564267 & 3909254 & 500 & $13 \pm 2$ & $6 \pm 2$ & $\begin{array}{l}12.1 \pm 0.6 \\
12.8 \pm 0.5 \\
11.5 \pm 0.2\end{array}$ & N/A \\
\hline Fenner Wash ${ }^{8}$ & 658533 & 3843945 & 520 & $12 \pm 2$ & $6 \pm 2$ & $\begin{array}{r}12.1 \pm 0.77 \\
11.1 \pm 0.3 \\
10.6 \pm 0.26\end{array}$ & N/A \\
\hline Coyote Wash ${ }^{8}$ & 522313 & 3875008 & 540 & $11 \pm 2$ & $9 \pm 2$ & $<13.6 \pm 0.3$ & N/A \\
\hline Sheep Creek ${ }^{8}$ & 451338 & 3829441 & 870 & $10 \pm 2$ & $5 \pm 2$ & $\begin{array}{l}10.6 \pm 0.56 \\
11.8 \pm 0.56\end{array}$ & $\begin{array}{l}7.74 \pm 0.54 \\
8.31 \pm 0.51 \\
9.44 \pm 0.49\end{array}$ \\
\hline Johnson V. ${ }^{10}$ & $550100^{6}$ & $3796840^{6}$ & 980 & $8 \pm 2$ & $6 \pm 2$ & $\begin{array}{r}<12.3 \pm 0.9 \\
10.3 \pm 1.1\end{array}$ & N/A \\
\hline Grassy V. ${ }^{8}$ & 477828 & 3902734 & 1040 & $6 \pm 2$ & $5 \pm 2$ & $<10.6 \pm 0.6$ & N/A \\
\hline
\end{tabular}

in the source catchments with the age of the woodland-todesert scrub transition using the solid curve in Fig. 3. Then, for each pixel in the study site, the percent of the upland source catchment that has undergone a change from commonness/abundance to rarity/absence of Juniperus is computed in $1 \mathrm{ka}$ intervals starting at $15 \mathrm{ka}$ cal BP. For example, at $15 \mathrm{ka}$ only the lowest elevations (i.e., those less than or equal to $750 \mathrm{~m}$ a.s.1.) of source catchments have undergone a change from commonness/abundance to rarity/absence of $\mathrm{Ju}$ niperus; hence, pixels downstream of such basins will record relatively low percentages for the percentage of the upstream source catchment basin that has undergone such a change. As time passes and woodlands retreat to higher elevations, the GIS analysis computes a progressively larger percentage of each source catchment that has transitioned from commonness/abundance to rarity/absence of Juniperus. The GIS analysis requires a map of the source catchment domain for each downstream pixel. The mapping of contributing area is performed in this study using the multiple-flow-direction (MFD) algorithm of Freeman (1991). I used the MFD method of Freeman (1991) to delineate source areas because it more faithfully represents flow routing pathways in distributary channel systems (which are common in the study area) compared with alternatives such as the $D \propto$ method (Pelletier, 2008).

When $5 \%$ of the source catchment area has undergone a change from commonness/abundance to rarity/absence of Juniperus, primary aggradation is assumed to be initiated. Similarly, when $50 \%$ of the source catchment area has undergone a change from commonness/abundance to rarity/absence of Juniperus, channel incision/secondary aggradation is assumed to be initiated. The 5 and $50 \%$ threshold values are not unique, but the results are not highly sensitive to these values within reasonable ranges; i.e., the predicted ages of aggradation and incision differ by $2 \mathrm{ka}$ or less for 96.5 and $98.6 \%$ of the study area where aggradation is predicted to occur as these values are varied over reasonable ranges from 5 to $15 \%$ and 40 to $60 \%$, respectively. The systematic uncertainty of the GIS analysis is taken to be approximately $2 \mathrm{ka}$ (Table 1) based on the uncertainty associated with the 5 and $50 \%$ thresholds as well as the uncertainty of the timing 


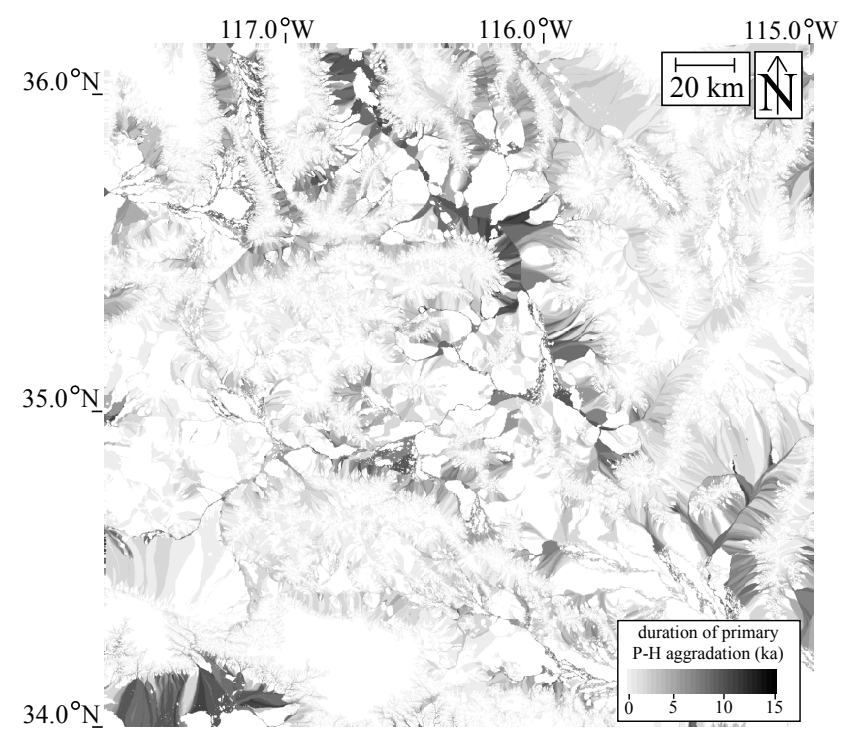

Figure 5. Grayscale map of the duration of primary aggradation associated with vegetation changes of the latest Pleistocene to midHolocene in the Mojave Desert (study area is the same as that shown in Fig. 4). Values range from $4-8 \mathrm{ka}$ cal at alluvial sites fed by catchments with a wide range of elevations in the 750-1800 m range (typically lower-elevation sites) to 1-4 ka cal at sites fed by catchments with a smaller range of such elevations (typically higher-elevation sites).

of the woodland-to-desert scrub transition at each elevation (i.e., the solid curve in Fig. 3).

The results of the GIS analysis indicate that the PVCH predicts that the initiation of primary aggradation associated with vegetation changes from the latest Pleistocene to the present was highly variable in space and occurred over a wide range of time from ca. 15-6 ka cal BP (but possibly earlier given uncertainty in the timing of woodland-to-desertscrub transition at the lowest elevations ca. $17-15 \mathrm{ka}$ cal BP; see dashed line in Fig. 3). According to the PVCH, aggradation began earlier at sites fed by catchments of lower elevation and later at sites fed by catchments of higher elevation (Figs. 4, 6, 7; Table 1). The predictions of the PVCH are consistent with eight out of nine fan-aggradation sites in the Mojave Desert (Table 1). The PVCH predicts that the duration of primary aggradation (which is also equivalent to the time lag between the initiation of primary aggradation and channel incision/secondary aggradation) was also highly variable, ranging from $4-8 \mathrm{ka}$ at sites fed by catchments with a wide range of elevations in the $750-1800 \mathrm{~m}$ range to $1-4 \mathrm{ka}$ at sites fed by catchments with a smaller range of such elevations (Fig. 5, Table 1).

It should be noted that the GIS analysis predicts the timing of aggradation in some upland catchments where fill terraces may not form or may not be preserved. It is nevertheless appropriate to include such areas in the analysis because aggradation can occur locally in such areas. Fill terraces
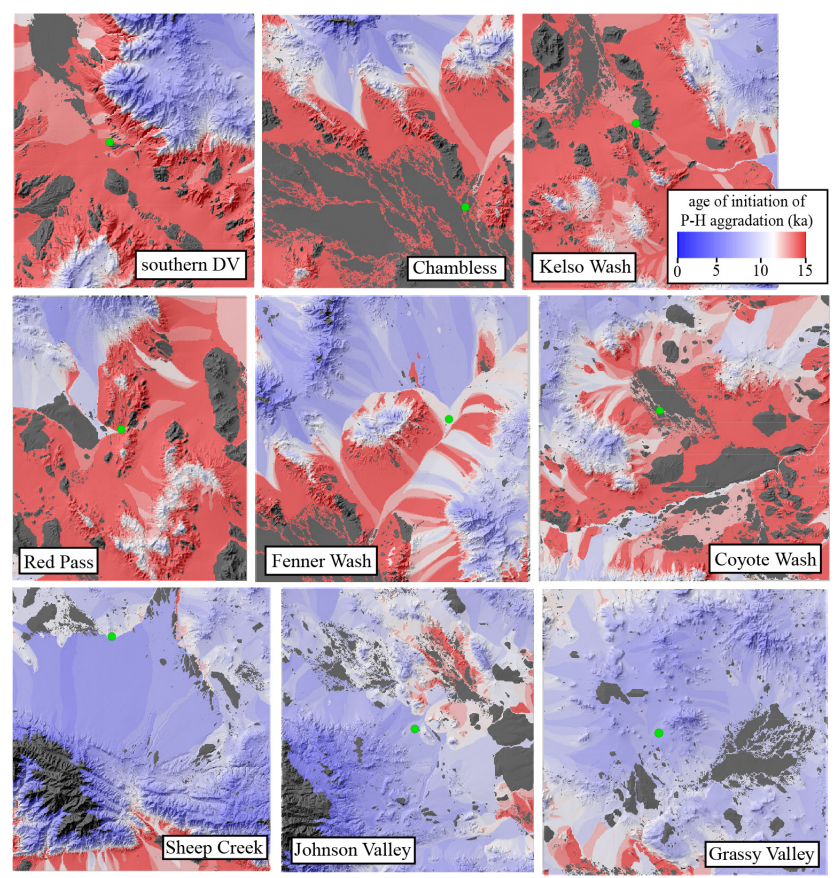

Figure 6. Subsets of Fig. 4 shown in greater detail and overlain on a shaded-relief image for each of the nine areas where the timing of fan aggradation is reasonably well constrained. Study areas are shown as lowest to highest elevation (of the dated sample locations) from upper left to lower right. The predicted age of initiation occurs systematically later at higher elevations, as also documented in Table 1 and Fig. 7.

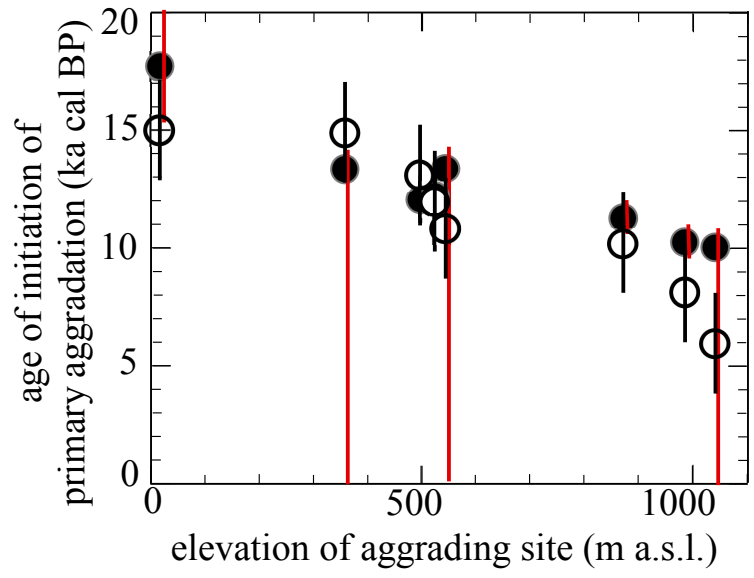

Figure 7. Plot of measured (closed circles) and predicted (open circles) ages of the initiation of primary aggradation according to the PVCH. All data from Table 1 are plotted except for Chambless site, which was not included because of ambiguity in whether the site represents primary or secondary aggradation (see Sect. 4 for discussion). Uncertainties of the measured ages are shown in red. Ages increase with decreasing elevation of the site of aggradation (which correlates with the lowest elevations of the source catchments). Uncertainty values are provided and explained in Table 1 . 


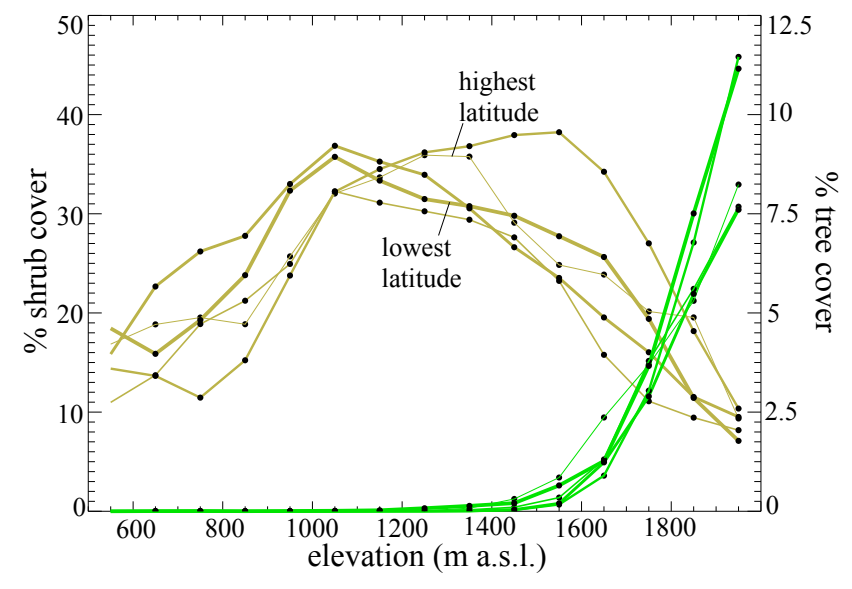

Figure 8. Plot of the average percent shrub (in brown) and tree (in green) cover in the Mojave Desert as a function of elevation for 5 bins of latitude (thinner lines indicate higher latitudes) using the US Geological Survey's (2013) LANDFIRE database. The data exhibit some spatial variation in the vegetation-cover-versus-elevation relationship, but there is no systematic difference across latitudes.

are preserved, for example, in many high-elevation, rapidly eroding catchments of the Transverse Ranges (located in the SW corner of the study area) (Bull, 1991). A more sophisticated analysis would predict the timing of both aggradation/incision and the likelihood of preservation of a fill deposit, but such an approach would introduce new parameters into the analysis and is unnecessary for addressing the key questions of this paper (i.e., the timing of aggradation and incision). Also, flow-routing pathways are identified using the modern DEM (the US National Elevation Dataset), yet channels have been modified by late-Quaternary fluvial-system aggradation and incision. As such, some portions of alluvial fans and lowland basins comprised of late-Pleistocene and/or Holocene deposits are now disconnected from source catchments (via channel incision and terrace abandonment) and hence appear as black in Figs. 4-6. In such areas one can estimate the predictions of the $\mathrm{PVCH}$ approximately using the predicted ages from nearby areas of similar elevation.

The study region considered in this paper is large; i.e., the entire Mojave Desert and some portions of adjacent regions. Adopting such a large study area has the advantage that a lot of data can be brought to bear in order to precisely constrain the relationship between vegetation changes, elevation, and time/age (Fig. 3). One could argue, however, that the study area (Fig. 4) is too large for a single paleovegetation change vs. age relationship (i.e., Fig. 3) to be applicable throughout the region (as assumed in the above analysis). We can address this issue, at least for modern vegetation (Fig. 8). I used gridded $30 \mathrm{~m} /$ pixel estimates of shrub and tree cover from the US Geological Survey's (2013) LANDFIRE database to quantify the relationship between percent shrub/tree cover and elevation using $100 \mathrm{~m}$ bins of elevation from 500 to $2000 \mathrm{~m}$ a.s.l. LANDFIRE is a US Geological Survey mapping program that produces high-resolution geospatial data for vegetation and fire regimes in the US. I divided the study region illustrated in Fig. 4 (i.e., $34-36.2^{\circ} \mathrm{N}, 115-117.8^{\circ} \mathrm{W}$ ) into five equally spaced bins of latitude and computed the relationship between average shrub/tree cover and elevation for each bin separately (Fig. 8). The results demonstrate that there is no systematic change in the relationship between modern vegetation cover and elevation with latitude from 34 to $36.2^{\circ} \mathrm{N}$ in the Mojave Desert. That is not to say that elevation is a perfect predictor of vegetation cover. Clearly, slope gradient and aspect, spatial variations in soil properties, etc. influence the elevational zonation of plants in the southwestern US locally. The scatter of the data plotted in Fig. 8 reflects the significant spatial variations in plant cover that exist within areas of equal elevation. Rather, this analysis demonstrates that any systematic differences in average vegetation cover across latitudes is much smaller than the differences across elevation.

\section{An improved process model for $\mathrm{PVCH}$}

Melton (1957) documented a strong positive correlation between drainage density and both aridity and percent bare area in the southwestern US. Melton's findings provide a basis for predicting an increase in drainage density during semiaridto-arid transitions. Similarly, Pelletier et al. (2013) quantified drainage density across the elevation/precipitation/vegetation gradient of the Santa Catalina Mountains in Arizona (from Sonoran desert scrub at low elevations that have a mean annual precipitation of $0.2 \mathrm{~m} \mathrm{a}^{-1}$ through pinyon/juniper woodland to mixed conifer forest at high elevations that have a mean annual precipitation of $0.8 \mathrm{~m} \mathrm{a}^{-1}$ ) and obtained a similar inverse relationship between drainage density and wateravailability/vegetation cover. Unfortunately, we lack studies that demonstrate an increase in sediment yield from hillslopes and/or drainage density resulting from a transition from woodland to desert scrub vegetation in the Mojave Desert specifically. However, anthropogenic disturbances in the Mojave Desert that are associated with reductions in vegetation cover consistently result in higher erosion rates from hillslopes and low-order fluvial valleys (e.g., Lovich and Bainbridge, 1999; Iverson, 1980, and references therein).

Theoretical models for the controls on drainage density further suggest that vegetation cover is the most important climatically related variable controlling drainage density. Perron et al. $(2008,2009)$, for example, demonstrated that the spacing of first-order valleys (closely related to drainage density) is a function of the relative rates of colluvial sediment transport (dominant on hillslopes) and slope-wash/fluvial erosion (dominant in valley bottoms). A reduction in vegetation cover decreases the rate of colluvial sediment transport because fewer plants are present to drive bioturbation, while simultaneously increasing slope-wash/fluvial-erosion rates via a reduction in protective cover. Both of these effects combine to promote higher drainage density. Multiple lines 


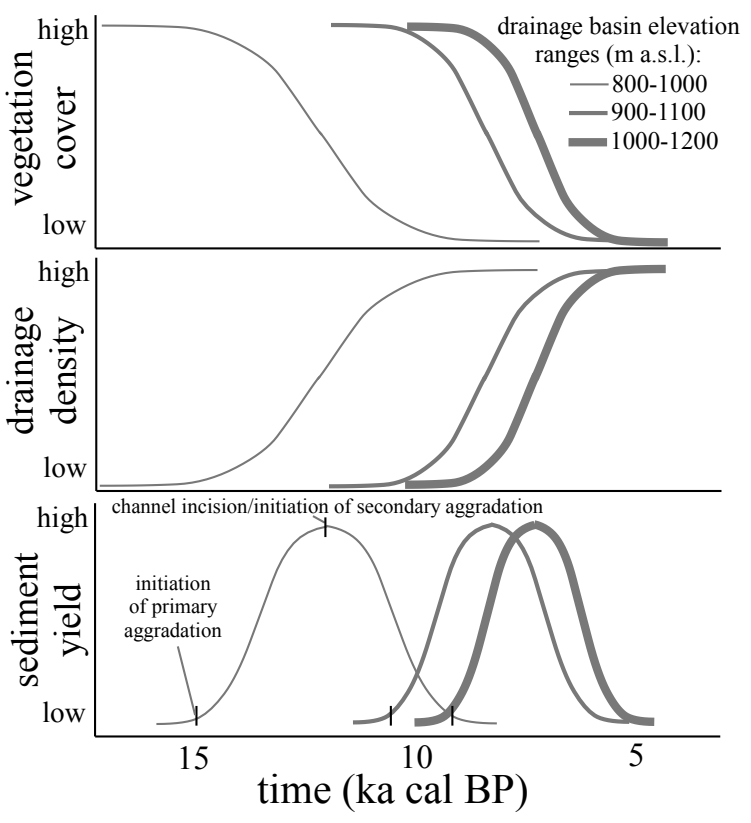

Figure 9. Conceptual model illustrating relationships among vegetation cover, drainage density, and sediment yield from source catchments for three hypothetical catchments (each with $200 \mathrm{~m}$ of relief) of different mean elevation.

of evidence also indicate that sediment yield is far more sensitive to changes in vegetation cover (via a threshold shear stress for detachment or entrainment) than changes in runoff intensity (Tucker and Slingerland, 1997). The critical shear stress criterion for detachment is (Tucker and Slingerland, 1997)

$P_{S} A S^{2}>\tau_{\mathrm{c}}^{3}$,

where $P_{S}$ is runoff $\left(\mathrm{L} \mathrm{T}^{-1}\right), A$ is contributing area $\left(\mathrm{L}^{2}\right), S$ is slope $(\mathrm{L} / \mathrm{L})$, and $\tau_{\mathrm{c}}$ is the shear stress threshold that depends on vegetation cover $\left(\mathrm{L} \mathrm{T}^{-1 / 3}\right)$. Equation (1) shows that a twofold decrease in $\tau_{c}$ is equivalent to an eightfold increase in in runoff intensity. I cannot quantify $\tau_{\mathrm{c}}$ for desert scrub versus woodland vegetation types, but Prosser and Dietrich (1995), working in central coastal California, documented a strong sensitivity of $\tau_{\mathrm{c}}$ to percent bare area, and Melton (1957) documented a strong correlation between drainage density and both aridity and percent bare area in the southwestern US. The results of Prosser and Dietrich (1995) were obtained in the relatively humid climate of coastal California, but Al-Hamdan et al. (2013) developed a theoretical model that suggests the sensitivity of erosion to bare area is a general phenomenon. According to Eq. (1), a twofold decrease in $\tau_{c}$ can increase the drainage density (which goes as the square root of contributing area) by almost threefold.

Figure 9 presents a schematic diagram of an alternative conceptual model for the PVCH that includes elevation and is qualitatively based on the results of numerical modeling studies (e.g., Tucker and Slingerland, 1997). This fig- ure shows variations in sediment yield (bottom panel) resulting from hypothetical changes in mean vegetation cover (top panel) and drainage density (middle panel) for three hypothetical drainage basins with elevations of $800-1000$, 900-1100, and 1000-1200 m a.s.l. The lowest drainage basin (800-1000 $\mathrm{m}$ a.s.l.) experiences the initiation of aggradation first (ca. $15 \mathrm{ka}$ cal BP) because the loss of Juniperus is time-transgressive, proceeding from low to high elevations through time. Numerical models predict that sediment pulses produced via an increase in drainage density are temporary (i.e., they are sediment pulses with both waxing and waning phases) because first-order valley heads eventually stabilize (following a transition from lower to higher drainage density) as they become adjusted to a smaller contributing area associated with the lower vegetation cover and hence lower shear stress threshold for detachment associated with arid climates. As such, the accelerating increase in drainage density that occurs in the 15-12 ka time interval for the lowest drainage basin is accompanied by an increase in sediment yield to a peak value of ca. $12 \mathrm{ka}$ (Fig. 9). Numerical models demonstrate that the stabilization of valley heads following drainage-network expansion causes a reduction in sediment supply that triggers channel incision, terrace abandonment, and secondary aggradation further downstream (Tucker and Slingerland, 1997) (ca. $12 \mathrm{ka}$ for the lowest drainage basin). The response of the higher-elevation drainage basins is similar except that aggradation is delayed relative to lowerelevation drainage basins and the duration of primary aggradation is predicted to be somewhat shorter as a result of the increase in the rate of the recession of Juniperus at higher elevations (1100-1800 m a.s.l.) relative to lower elevations.

\section{Discussion}

Aggradation begins at a time consistent with the predictions of the PVCH in all cases except one (Chambless) in which the measured initiation of aggradation occurs significantly later than the prediction (Figs. 4-7; Table 1). There is no discrepancy, however, if the dated deposit at Chambless corresponds to a site of secondary aggradation (i.e., if sediments with a depositional age of ca. $15 \mathrm{ka}$ cal BP are located upstream) because the predicted age of channel incision/secondary aggradation according to the GIS analysis is consistent with the measured age (Table 1). The Chambless site is not included in Fig. 7 because of this ambiguity. The likelihood that two pulses of aggradation will occur from one pulse of sediment yield complicates testing of any model for late-Quaternary fluvial-system aggradation, but this complexity can be addressed in future studies with detailed geologic mapping and simultaneous dating of both primary and nearby/inset secondary late-Quaternary deposits.

In the two sites where the timing of incision is constrained (southern Death Valley and Sheep Creek), the model underpredicts the age of incision by approximately $3 \mathrm{ka}$. It is 
difficult to draw conclusions from a sample size of two, but the discrepancy between the predicted and measured incision ages could be due to the relatively large uncertainty of the timing of paleovegetation changes within the 10-3 ka interval and/or the relatively large uncertainty associated with ages of incision measured (as done here) using the highest stratigraphic age (which necessarily overestimates the age of incision).

The results of this paper are consistent with the timetransgressive nature of aggradation and incision with elevation documented by Weldon (1986) in his study of the lateQuaternary history of Cajon Pass (located near the southwestern corner of the study area shown in Fig. 4) despite the more Mediterranean climate of the Transverse Ranges and the associated differences in vegetation types compared with the Mojave Desert (Fig. 10). Weldon (1986) documented a wave of aggradation followed by incision that moved up Cajon Pass from elevations of 500 (i.e., the Freeway Crossing) to $1500 \mathrm{~m}$ a.s.l. (the summit) during the time interval from 15 to $6 \mathrm{ka}$ cal BP (Fig. 10a). Weldon's (1986) study is particularly valuable because it demonstrates the time-transgressive nature of aggradation with elevation at a single site rather than by combining many study sites within a large region. Weldon (1986) also demonstrated that the hillslope sediment yield from 15 to $6 \mathrm{ka}$ cal BP was an order of magnitude higher than sediment yields during either the late Pleistocene or the mid-late Holocene. The PVCH accurately predicts the time-transgressive wave of aggradation documented by Weldon (1986) (Fig. 10c).

The PVCH purportedly fails in two sites considered by Antinao and McDonald (2013a), i.e., the western side of the Providence Mountains (dated by Clarke, 1994) and the Sierra El Mayor piedmont of Baja California deposits (dated by Spelz et al., 2008; Armstrong et al., 2010). The Baja California sites are not part of the Mojave Desert but are important to address here because, according to Antinao and McDonald (2013a), they provide a basis for a reduced relevance of PVCH in the late-Quaternary evolution of the southwestern US. Fan aggradation is not always triggered by climatic variations, however, so it is important to consider other possible triggers for aggradation when evaluating the PVCH in specific cases. The Kelso Dunes have migrated across the distal portion of the western piedmont of the Providence Mtns. in late-Quaternary time. The site location map in Fig. 2 of Clarke (1994) and the stratigraphic columns in Fig. 3 of Clarke (1994) clearly show that the deposits dated by Clarke (1994) include aeolian sand deposits at least $1 \mathrm{~m}$ thick at each sample locality and grade to aeolian sand deposits at least $8 \mathrm{~m}$ thick at the distal end of the fan. Seven out of the eight sediment samples dated by Clarke (1994) were aeolian sediments and the sole fluvial sediment sample dated was located directly atop aeolian sediments. Therefore, despite the common interpretation that the Clarke (1994) ages record climatically driven fluvial-system aggradation, it is at least possible that the ages measured by Clarke (1994) more
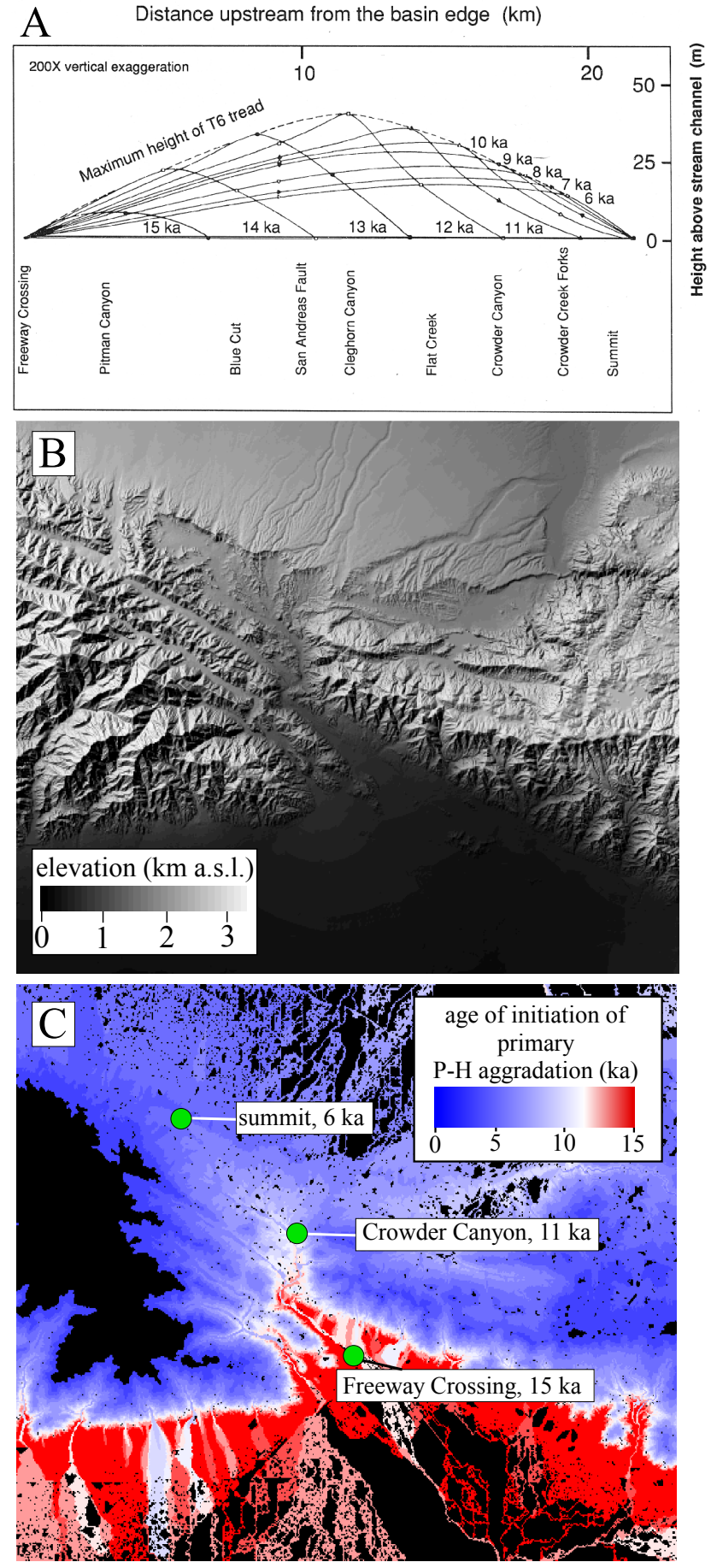

Figure 10. Comparison of (a) measured (from Bull, 1991 after Weldon, 1986) and (c) predicted age of initiation of primary aggradation in Cajon Pass, California, according to the PVCH. Location of (c) shown in Fig. 4. Shaded-relief map of the area shown in (b). 
strongly reflect the history of the Kelso Dunes in addition to fluvial aggradation triggered by the local base-level rise associated with the migration of the Kelso Dunes across the distal portion of the fan. Given this possibility, the Clarke (1994) data may not be the most reliable data to use when testing alternative models for the climatic triggering of fluvial-system aggradation.

Similarly, fan deposits on the eastern piedmont of Sierra El Mayor dated by Armstrong et al. (2010) are potentially problematic for the purposes of testing the PVCH because they were deposited atop, and shortly following deposition of, fluvial and deltaic sediments of the Colorado River (Armstrong et al., 2010), which today is located less than $1 \mathrm{~km}$ from the dated fan deposits. As such, aggradation of the Colorado River may have resulted in a local increase in base level, triggering aggradation of fan sediments without a climatically driven change in upstream sediment supply. Although the response of fluvial channels to base-level rise depends on a number of factors including the magnitude of the baselevel change and the slope of the channel affected by baselevel changes (Schumm, 1993), Leopold and Bull (1979) presented one specific example in which a modest increase in base level (i.e., $\sim 3 \mathrm{~m}$ ) triggered aggradation at a distance of $\sim 1 \mathrm{~km}$. As such, it is possible that deposition on the western piedmont of Sierra El Mayor is principally influenced by the base-level control exerted by the Colorado River rather than by a climatically driven increase in sediment supply.

Spelz et al. (2008) dated fan aggradation on the western piedmont of the Sierra El Mayor that is likely unaffected by the Colorado River. However, the cosmogenic ages of Spelz et al. (2008) on boulders of the terrace associated with latest Pleistocene aggradation varied by $300 \%$ (700\% if all of the data are considered - one date of $76 \mathrm{ka}$ cal BP was excluded in the average). As such, the age control at this site is not ideal. Spelz et al. (2008) used a weighted average of boulder ages to obtain an estimated surface age of $15.5 \pm 2.2 \mathrm{ka}$ cal BP (i.e., well before the retreat of late-Pleistocene plants at $10.7 \pm 0.5 \mathrm{ka}$ cal BP as constrained by the presence of boojum trees (Fouquieria columnaris) (Anderson and Van Devender, 1995)). However, a more accurate surface-exposure age is, in many cases, obtained by using the youngest boulder age that is not an obvious outlier, especially when inheritance is a potentially important factor (e.g., Applegate et al., 2010; Heyman et al., 2011). In this case that age would be $11 \pm 1.3 \mathrm{ka}$ cal BP; i.e., broadly consistent with the timing of paleovegetation changes.

Many authors, including Bull (1991), Harvey et al. (1999), McDonald et al. (2003), Miller et al. (2010), and Antinao and McDonald (2013a, b) have invoked changes in the frequency and/or intensity of extreme storms to drive fluvial-system aggradation in the southwestern US. Miller et al. (2010), for example, documented a correlation between sea-surface temperatures in the Gulf of California (a proxy for monsoon activity) and alluvial-fan aggradation in the Mojave Desert. The role of monsoon thunderstorms specifically in driving aggradation in the Mojave Desert is uncertain given the limited impact of the North American Monsoon (NAM) system on the Mojave Desert (Higgins et al., 1997). Recent investigations of the spatial extent of NAM show no significant impact on the Mojave Desert (e.g., Dominguez et al., 2009). The correlation between sea-surface temperatures in the Gulf of California (which drive NAM storms) and alluvial-fan aggradation in the Mojave Desert is excellent for the 6-3 ka cal BP time period but significantly poorer for the latest-Pleistocene-to-early-Holocene time period; i.e., primary aggradation occurred ca. $14-7 \mathrm{ka}$ cal BP while elevated sea-surface temperatures occurred $15-11 \mathrm{ka} \mathrm{cal} \mathrm{BP}$.

Antinao and McDonald (2013b) argued, as an alternative to the NAM-driven extreme-storm hypothesis of Miller et al. (2010), that more frequent and/or intense El-Niñolike conditions in the tropical Pacific increased moisture delivery to the southwestern US ca. $14.5-8 \mathrm{ka}$ cal BP, triggering fan aggradation. It is clear that dissipating tropical storms are responsible for generating most of the extreme floods in the historical record in drainage basins larger than $\sim 10^{3} \mathrm{~km}^{2}$ in the Mojave and Sonoran deserts, including tropical storms Norma (1970), Kathleen (1976), Octave (1983), and Nora (1997). As such, the importance of tropical storms in triggering modern regional flooding in the southwestern US is undeniable. The relative importance of monsoon versus tropical storms is largely a function of drainage-basin area, with tropical storms dominating the largest floods for many drainage basins greater than $\sim 10^{3} \mathrm{~km}^{2}$ and NAM-driven convective storms dominating the extreme-storm record for many smaller drainage basins (e.g., Hirschboeck, 1988).

It is unclear, however, whether either of these mechanisms (increased monsoon activity or increased El-Niño-like conditions driving more frequent or more intense tropical storm activity) is consistent with the time-transgressive nature of fluvial-system aggradation in the Mojave Desert with elevation, in which the initiation of primary aggradation occurred earlier (i.e., ca. 15-12 ka cal BP) at lower-elevation sites, 400-900 m a.s.l., and later (i.e., ca. 12-6 ka cal BP) at higher-elevation sites, $900-1500 \mathrm{~m}$. More fundamentally, it is equally unclear whether an increase in the frequency or intensity of extreme storms is more likely to trigger fan aggradation or incision. Fluvial-system aggradation requires an increase in sediment yield from hillslopes without a comparable increase in the ability of fluvial channels to transport that increase in sediment (aggradation can also be triggered by a decrease in the ability of fluvial channels to transport sediment without any change in sediment supply from hillslopes, but this scenario is not relevant to the extreme-storm hypothesis since more intense storms are unlikely to be less effective at transporting the sediment delivered to them compared with less intense storms). That is, any climate change that simultaneously increases hillslope sediment yield and the ability of fluvial channels to convey that increase in sediment yield might not result in aggradation except in the 
lowest elevations of closed basins (e.g., playas). In contrast, the conceptual model for the PVCH presented here predicts valley-floor and alluvial-fan aggradation specifically because the sediment pulse from hillslopes was not accompanied by a significant increase in the ability of fluvial channels to convey that increase in sediment yield. It is certainly possible that periodic episodes of increasing tropical-storm activity accompanied vegetation changes to generate the lateQuaternary alluvial record of the Mojave Desert. As such, more research is needed to distinguish among these hypotheses and/or demonstrate how they act in concert.

The PVCH may be applicable to other sites worldwide that have experienced a transition from semiarid to arid climates during the late Quaternary. Due to the fact that constraints on paleovegetation and the timing of fluvial-system aggradation are rarely present in the same location, however, the $\mathrm{PVCH}$ has rarely been tested outside of the deserts of North America (where packrat middens are available and have been studied for decades, for example). An exception is the Nahal Yael, a drainage basin in southern Israel where Bull and Schick (1979) applied an early version of the Bull (1991) model. Enzel et al. (2012) recently showed that the Nahal Yael did not experience a semiarid-to-arid climatic transition, however. As such, the PVCH does not apply to that site. The case of the Nahal Yael underscores the importance of having reliable local paleoclimate/paleovegetation data when attempting to apply or test the PVCH.

\section{Conclusions}

This paper builds upon previous studies (e.g., Weldon, 1986) as well as comprehensive new geochronologic studies (e.g., Miller et al., 2010) to further demonstrate that fluvial-system aggradation from the latest Pleistocene to the present in the southwestern US was time-transgressive with elevation. As such, the timing of the initiation of primary fluvial-system aggradation and channel incision/secondary aggradation exhibit spatial variability that depends sensitively on the elevation ranges of source catchments. In order to predict these timings for specific locations using the $\mathrm{PVCH}$, I tightly constrained the relationship between paleovegetation changes and elevation and then used a GIS analysis that incorporated the elevation ranges of source catchments. The PVCH predicts the correct timing of the initiation of aggradation in eight out of nine cases in the Mojave Desert where reasonable age control exists. It is likely that changes in the frequency or intensity of extreme storms have contributed to cycles of fluvial-system aggradation and incision in the southwestern US, but the results of this paper suggest that the recent trend of discounting the importance of hillslope vegetation changes deserves reexamination.
Acknowledgements. This work was partially supported by NSF award no. 0309518. I wish to thank Phil Pearthree and Vic Baker for comments on an early draft that helped me to improve the paper. P. Kyle House, Arnaud Temme, and two anonymous reviewers provided helpful reviews during the review process that led to a significantly improved paper.

Edited by: A. Temme

Reviewed by: P. K. House and two anonymous referees

\section{References}

Al-Hamdan, O. Z., Pierson, F. B., Nearing, M. A., Williams, C. J., Stone, J. J., Kormos, P. R., Boll, J., and Weltz, M. A.: Risk assessment of erosion from concentrated flow on rangelands using overland flow distribution and shear stress partitioning, Trans. Am. Soc. Agri. Biol. Eng., 56, 539-548, doi:10.13031/2013.42684, 2013.

Anders, M. D., Pederson, J. L., Rittenour, T. M., Sharp, W. D., Gosse, J. C., Karlstrom, K. E., Crossey, L. J., Goble, R. J., Stockli, L., and Yang, G.: Pleistocene geomorphology and geochronology of eastern Grand Canyon: linkages of landscape components during climate changes, Quaternary Sci. Rev., 24, 2428-2448, doi:10.1016/j.quascirev.2005.03.015, 2005.

Anderson, R. S. and Van Devender, T. R.: Vegetation history and paleoclimates of the coastal lowlands of Sonora, Mexico - pollen records from packrat middens, J. Arid Environ., 30, 295-306, doi:10.1016/S0140-1963(05)80004-7, 1995.

Antinao, J.-L. and McDonald, E.: A reduced relevance of vegetation change for alluvial aggradation in arid zones, Geology, 41, 1114, doi:10.1130/G33623.1, 2013a.

Antinao, J.-L. and McDonald, E.: An enhanced role for the Tropical Pacific on the humid Pleistocene-Holocene transition in southwestern North America, Quaternary Sci. Rev., 78, 319-341, doi:10.1016/j.quascirev.2013.03.019, 2013b.

Applegate, P. J., Urban, N. M., Laabs, B. J. C., Keller, K., and Alley, R. B.: Modeling the statistical distributions of cosmogenic exposure dates from moraines, Geosci. Model Devel., 3, 293-307, doi:10.5194/gmd-3-293-2010, 2010.

Armstrong, P., Perez, R., Owen, L. A., and Finkel, R. C.: Timing and controls on late Quaternary landscape development along the eastern Sierra el Mayor, northern Baja California, Mexico, Geomorphology, 114, 415-430, doi:10.1016/j.geomorph.2009.08.005, 2010.

Bull, W. B.: The alluvial fan environment, Progr. Phys. Geog., 1, 222-270, doi:10.1177/030913337700100202, 1968.

Bull, W. B.: Geomorphic responses to climatic change, Oxford, UK, Oxford University Press, p. 326, doi:10.1002/gea.3340080106, 1991.

Christensen, G. E. and Purcell, C.: Correlation and age of Quaternary alluvial-fan sequences, Basin and Range province, southwestern Unites States, in: Soils and Quaternary Geology of the Southwestern United States, edited by: Weide, D. L., Geological Society of America Special Paper 203, 115-122, 1985.

Clarke, M. L.: Infrared stimulated luminescence ages from aeolian sand and alluvial fan deposits from the eastern Mojave Desert, California, Quaternary Geochronology, Quaternary Sci. Rev., 13, 533-538, doi:10.1016/0277-3791(94)90073-6, 1994. 
Dominguez, F., Villegas, J. C., and Breshears, D. D.: Spatial extent of the North American Monsoon: Increased cross-regional linkages via atmospheric pathways, Geophys. Res. Lett., 36, L07401, doi:10.1029/2008GL037012, 2009.

Enzel, Y., Amit, R., Grodek, T., Ayalon, A., Lekach, J., Porat, N., Bierman, P., Blum, J. D., and Erel, Y.: Late Quaternary weathering, erosion, and deposition in Nahal Yael, Israel: An "impact of climatic change on an arid watershed"?, Geol. Soc. Am. Bull., 124, 705-722, doi:10.1130/B30538.1, 2012.

Freeman, G. T.: Calculating catchment area with divergent flow based on a rectangular grid, Comput. Geosci., 17, 413-422, 1991.

Harvey, A. M., Wigand, P. E., and Wells, S. G.: Response of alluvial fan systems to the late Pleistocene to Holocene climatic transition, Contrasts between the margins of pluvial Lakes Lahontan and Mojave, Nevada and California, USA, Catena, 36, 255-281, 1999.

Held, I. M. and Soden, B. J.: Robust responses of the hydrological cycle to global warming, J. Climate, 19, 5686-5699, doi:10.1175/JCLI3990.1, 2006.

Heyman, J., Stroeven, A. P., Harbor, J. M., and Caffee, M. W.: Too young or too old: Evaluating cosmogenic exposure dating based on an analysis of compiled boulder exposure ages, Earth Planet Sci. Lett., 302, 71-80, doi:10.1016/j.epsl.2010.11.040, 2011.

Higgins, R. W., Yao, Y., and Wang, X. L.: Influence of the North American Monsoon System on the U.S. Summer Precipitation Regime, J. Climate, 10, 2600-2622, doi:10.1175/15200442(1997)010<2600:IOTNAM>2.0.CO;2, 1997.

Hirschboeck, K. K.: Flood hydroclimatology, in Flood Geomorphology, edited by: Baker, V. R., Kochel, R. C., and Patton, P. C., John Wiley \& Sons, 189-205, 1988.

Iverson, R. M.: Processes of accelerated pluvial erosion on desert hillslopes modified by vehicular traffic, Earth Surf. Proc. Landf., 5, 369-388, doi:10.1002/esp.3760050407, 1980.

Kort, J., Collins, M., and Ditsch, D.: A review of soil erosion potential associated with biomass crops, Biomass Bioenerg., 14, 351359, doi:10.1016/S0961-9534(97)10071-X, 1998.

Langbein, W. B. and Schumm, S. A.: Yield of sediment in relation to mean annual precipitation, Am. Geophys. Union Trans., 39, 1076-1084, doi:10.1029/TR039i006p01076, 1958.

Lau, W. K.-M., Wu, H.-T., and Kim, K.-M.: A canonical response of precipitation characteristics to global warming from CMIP5 models, Geophys. Res. Lett., 40, 3163-3169, doi:10.1002/grl.50420, 2013.

Leopold, L. B. and Bull, W. B.: Base level, aggradation, and grade, Proc. Am. Phil. Soc., 123, 168-202, 1979.

Lovich, J. E. and Bainbridge, D.: Anthropogenic Degradation of the Southern California Desert Ecosystem and Prospects for Natural Recovery and Restoration, Environ. Manag., 24, 309-326, doi:10.1007/s002679900235, 1999.

Mahan, S. A., Miller, D. M., Menges, C. M., and Yount, J. C.: Late Quaternary stratigraphy and luminescence geochronology of the northeastern Mojave Desert, Quaternary Int., 166, 61-78, 2007.

McDonald, E. V., McFadden, L. D., and Wells, S. G.: Regional response of alluvial fans to the Pleistocene-Holocene climatic transition, Mojave Desert, California, in: Paleoenvironments and paleohydrology of the Mojave and southern Great Basin deserts, edited by: Enzel, Y., Wells, S. G., and Lancaster, N., Geological Society of America Special Paper 368, 189-205, 2003.
Melton, M. A.: An analysis of the relations among elements of climate, surface properties, and geomorphologym Tech. Rept. 11, Project NR 389-042, Office of Naval Research, Department of Geology, Columbia University, New York, 1957.

Menges, C. M., Taylor, E. M., Workman, J. B., and Jayko, A. S.: Regional surficial deposit mapping in the Death Valley area of California and Nevada in support of ground- water modeling, in: Quaternary and Late Pliocene Geology of the Death Valley Region - Recent Observations on Tectonics, Stratigraphy, and Lake Cycles, edited by: Machette, M. N., Johnson, M. L., and Slate, J. L., Pacific Cell Friends of the Pleistocene Field Trip, February 17-19, 2001, H151-H166, US Geological Survey Open-File Report 01-51, 2001.

Miller, D. M., Schmidt, K. M., Mahan, S. A., McGeehin, J. P., and Owen, L. A.: Holocene landscape response to seasonality of storms in the Mojave Desert, Quaternary Int., 215, 45-61, doi:10.1016/j.quaint.2009.10.001, 2010.

Murray, A. B., Lazarus, E., Ashton, A., Baas, A., Coco, G., Coulthard, T., Fonstad, M., Haff, P., McNamara, D., Paola, C., Pelletier, J., and Reinhardt, L.: Geomorphology, complexity, and the emerging science of the Earth's surface, Geomorphology, 103, 496-505, doi:10.1016/j.geomorph.2008.08.013, 2009.

Pelletier, J. D.: Quantitative Modeling of Earth Surface Processes, Cambridge University Press, New York, doi:10.1017/CBO9780511813849, 2008.

Pelletier, J. D., Quade, J., Goble, R. J., and Aldenderfer, M. S.: Widespread hillslope gullying on the southeastern Tibetan Plateau: Human or climate-change induced?, Geol. Soc. Am. Bull., 123, 1926-1938, doi:10.1130/B30266.1, 2011.

Pelletier, J. D., Barron-Gafford, G. A., Breshears, D. D., Brooks, P. D., Chorover, J., Durcik, M., Harman, C. J., Huxman, T. E., Lohse, K. A., Lybrand, R., Meixner, T., McIntosh, J. C., Papuga, S. A., Rasmussen, C., Schaap, M., Swetnam, T. L., and Troch, P. A.: Coevolution of nonlinear trends in vegetation, soils, and topography with elevation and slope aspect: A case study in the sky islands of southern Arizona, J. Geophys. Res. Earth Surf., 118, 741-758, doi:10.1002/jgrf.20046, 2013.

Perron, J. T., Dietrich, W. E., and Kirchner, J. W.: Controls on the spacing of first-order valleys, J. Geophys. Res., 113, F04016, doi:10.1029/2007JF000977, 2008.

Perron, J. T., Kirchner, J. W., and Dietrich, W. E.: Formation of evenly spaced ridges and valleys, Nature, 460, 502-505, doi:10.1038/nature08174, 2009.

Pierson, F. B., Bates, J. D., Svejcar, T. J., and Hardegree, S. P.: Runoff and erosion after cutting western juniper, Rangeland Ecol. Manag., 60, 285-292, 2007.

Prosser, I. P. and Dietrich, W. E.: Field experiments on erosion by overland flow and their implication for a digital terrain model of channel initiation, Water Resour. Res., 31, 2867-2876, doi:10.1029/95WR02218, 1995.

Reimer, P. J., Baillie, M. G. L., Bard, E., Bayliss, A., Beck, J. W., Blackwell, P. G., Bronk Ramsey, C., Buck, C. E., Burr, G. S., Edwards, R. L., Friedrich, M., Grootes, P. M., Guilderson, T. P., Hajdas, I., Heaton, T. J., Hogg, A. G., Hughen, K. A., Kaiser, K. F., Kromer, B., McCormac, F. G., Manning, S. W., Reimer, R. W., Richards, D. A., Southon, J. R., Talamo, S., Turney, C. S. M., van der Plicht, J., and Weyhenmeyer, C. E.: IntCal09 and Marine09 radiocarbon age calibration curves, 0-50,000 years cal BP, Radiocarbon, 51, 1111-1150, 2009. 
Reinhardt, L., Jerolmack, D. J., Cardinale, B., Vanacker, V., and Wright, J.: Dynamic interactions of life and its landscape: feedbacks at the interface of geomorphology and ecology: Earth Surf. Process. Landf., 35, 78-101, doi:10.1002/esp.1912, 2010.

Rockwell, T. K., Lindvall, S., Herzberg, M., Murbach, D., Dawson, T., and Berger, G.: Paleoseismology of the Johnson Valley, Kickapoo, and Homestead Valley faults: Clustering of earthquakes in the eastern California shear zone, Bull. Seis. Soc. Am., 90, 12001236, doi:10.1785/0119990023, 2000.

Schumm, S. A.: Geomorphic thresholds and complex response of drainage systems, in: Fluvial Geomorphology: SUNY Binghamton Publication in Geomorphology, edited by: Morisawa, M., 299-310, 1973.

Schumm, S. A.: River response to baselevel change: Implications for sequence stratigraphy, J. Geol., 101, 279-294, doi:10.1086/648221, 1993.

Sohn, M. F., Mahan, S. A., Knott, J. R., and Bowman, D. D.: Luminescence ages for alluvial fan deposits in Southern Death Valley: Implications for climate-driven sedimentation along a tectonically active mountain front, Quaternary Int., 166, 49-60, 2007.

Spelz, R. M., Fletcher, J. M., Owen, L. A., and Caffee, M. W.: Quaternary alluvial-fan development, climate and morphologic dating of fault scarps in Laguna Salada, Baja California, Mexico, Geomorphology, 102, 578-594, doi:10.1016/j.geomorph.2008.06.001, 2008.
Strahler, A. N.: Dimensional analysis applied to fluvially eroded landforms: Geol. Soc. Am. Bull., 69, 279-300, doi:10.1130/0016-7606(1958)69[279:DAATFE]2.0.CO;2, 1958.

Strickland, L. E., Thompson, R. S., Anderson, K. H., and Pelltier, R. T.: Late Quaternary biogeographic and climatic changes in western North America: Evidence from mapped arrays of packrat midden data, American Geophysical Union, Fall Meeting 2005, abstract PP11B-1470, 2005.

Tucker, G. E. and Slingerland, R.: Drainage basin response to climate change, Water Resour. Res., 33, 2031-2047, doi:10.1029/97WR00409, 1997.

US Geological Survey: LANDFIRE Existing Vegetation Type layer (2013, June - last update), US Department of Interior, Geological Survey, Digital data available at: http://landfire.cr.usgs.gov/ viewer/, 2013.

Weldon, R. J.: The late Cenozoic geology of Cajon Pass: implications for tectonics and sedimentation along the San Andreas fault, Ph.D. Dissertation, California Institute of Technology, 1986.

Whittaker, R. H. and Niering, W. A.: Vegetation of the Santa Catalina Mountains, Arizona. V. Biomass, Production, and Diversity along the Elevation Gradient, Ecology, 56, 771-790, doi:10.2307/1936291, 1975. 